\title{
Thermodynamic Analysis of a Semi-Closed Oxy-fuel Combustion Combined Cycle
}

\author{
R. P. Furtado ${ }^{*}$, R. P. Bereche ${ }^{2}$, A. D. Rocha ${ }^{3}$, A. G. Gallego ${ }^{4}$ \\ ${ }^{1,2,3,4}$ Center of Engineering, Modeling and Applied Social Sciences, Federal University of ABC, Santo André, Brazil \\ E-mail: ${ }^{1}$ rafaelpinho45@gmail.com, ${ }^{2}$ reynaldo.palacios@ufabc.edu.br, ${ }^{3}$ a.damiani@ufabc.edu.br, ${ }^{4}$ a.gallego@ufabc.edu.br
}

Received 03 July 2021, Revised 7 November 2021, Accepted 06 December 2021

\begin{abstract}
Semi-closed oxy-fuel combustion combined cycle (SCOC-CC) is a strong concept of carbon capture and storage (CCS) in gas-fired power plants. This technology is similar to a conventional combined cycle, however oxygen instead of air is used in fuel combustion. In the oxy-fuel combined cycle, the gas turbine flue gases consist mainly of $\mathrm{CO}_{2}$ and $\mathrm{H}_{2} \mathrm{O}$. One of the problems to implement this technology is the necessity of an air separation unit (ASU) to separate the oxygen from the air, which increases the energy consumption of the power plant. Thus, a comparative thermodynamic analysis was performed between a conventional combined cycle (base case) and an oxy-fuel combined cycle. The objective is to identify each technology's pros and cons, the influence of oxygen purity in the oxy-fuel combine cycle, and the main irreversibilities of each case. The SCOC-CC optimal operating point (maximum energy efficiency) was found utilizing particle swarm optimization (PSO), which lead to the optimal ASU oxygen purity of $95.99 \%$. It was noticed that the oxy-fuel combined cycle first law efficiency is $6.9 \%$ lower than the base case, and the second law efficiency is $6.5 \%$ lower. Despite the efficiency loss the SCOC-CC is more environmentally friendly than the conventional combined cycle since it can theoretically capture all $\mathrm{CO}_{2}$ produced in the combustion chamber.
\end{abstract}

\section{Keywords: Oxy-fuel; SCOC-CC; thermodynamic analysis; CCS; PSO.}

\section{Introduction}

Global warming and greenhouse gases emissions are the most significant environmental concerns nowadays. Carbon dioxide $\left(\mathrm{CO}_{2}\right)$ represented $81 \%$ of greenhouse gas emissions in 2019 [1]. The electricity and heat production sectors will remain heavily dependent on fossil fuels for the foreseeable future. For this reason, it is a need to find ways to reduce greenhouse gas emissions in thermal power plants. Oxy-fuel combustion is a promising carbon-capture technology in fossil-fueled power plants, as it can capture up to $98 \%$ of the $\mathrm{CO}_{2}$ produced in the combustion process, depending on the purification technique applied to remove $\mathrm{CO}_{2}$ from the flue gas, which contains between $75 \mathrm{~mol} \%$ and $90 \mathrm{~mol} \%$ of $\mathrm{CO}_{2}$ (dry basis), with nitrogen, oxygen, and argon as the major contaminants [2]. The oxy-fuel process utilizes nearly pure oxygen instead of air to burn the fuel. The combustion of a fuel with almost pure oxygen has a combustion temperature of about $3000^{\circ} \mathrm{C}$, which is too high for conventional power plant materials. The combustion temperature is limited to approximately $1300-1400^{\circ} \mathrm{C}$ in a typical gas turbine cycle and about $1900^{\circ} \mathrm{C}$ in a coal-fired boiler using current technology; thus, a part of the flue gases is recycled to the combustor to control the combustion temperature [3]. An air separation unit (ASU) is required in the power plant to obtain pure oxygen for combustion. Three main technologies are used to separate oxygen from the air: cryogenic distillation, adsorption using multi-bed pressure swing units, and polymeric membranes. The adsorption system would be the most appropriate technology for oxy-fuel processes that require less than 200 tonnes of $\mathrm{O}_{2}$ per day, while cryogenic distillation would be the most appropriate for larger applications [4]. The cryogenic distillation is the most mature and reliable among the aforementioned technologies, as it has been in practice for over 75 years [5]. Nevertheless, the main issue in oxy-fuel power plants is the high energy consumption of the ASU and the treatment of captured $\mathrm{CO}_{2}$. When combined, they can decrease the LHV (lower heating value) efficiency to about $10 \%$ [6].

The design of a semi-closed oxy-fuel combustion combined cycle (SCOC-CC) is very similar to a conventional combined cycle (CC), except for near-tostoichiometric combustion with oxygen instead of air in the gas turbine. The gas turbine flue gases, consisting mainly of $\mathrm{CO}_{2}$ and $\mathrm{H}_{2} \mathrm{O}$, supply energy to the heat recovery steam generator (HRSG), producing steam for the bottoming Rankine cycle. After the HRSG, the water in the flue gases is separated; then, most of the $\mathrm{CO}_{2}$ is recycled back to the gas turbine, while the remaining $\mathrm{CO}_{2}$ is purified and compressed for storage [7].

In this paper, a comparative analysis between a base case and an oxy-fuel combined cycle power plant is performed. The main goals of this comparison are: identifying the optimal operation point (maximal energy efficiency) of the SCOC-CC, the influence of oxygen purity on the oxy-fuel system, and identifying the main irreversibilities that occur in each case. Both cases were modeled on Engineering Equation Solver (EES) and optimized with particle swarm optimization algorithm (PSO) in Matlab.

\section{Methodology}

In this article, it was proposed to carry out a comparative analysis between a CC and a SCOC-CC. In the analysis, some characteristics were considered the same: a) turbine 
inlet temperature (TIT); b) fuel composition and consumption; c) condenser pressure.

\subsection{Thermodynamic Analysis}

The thermodynamic analysis was performed through mass balance, Eq. (1); energy balance, Eq. (2); and exergy balance Eq. (3). A control volume eclosing each component is at steady-state, and kinetic and potential energy effects are negligible.

$$
\left(\sum \dot{\mathrm{m}}_{\mathrm{i}}\right)_{\text {out }}=\left(\sum \dot{\mathrm{m}}_{\mathrm{i}}\right)_{\text {in }}
$$

$0=\dot{\mathrm{Q}}-\dot{\mathrm{W}}+\left(\sum \dot{\mathrm{m}}_{\mathrm{i}} \mathrm{h}_{\mathrm{i}}\right)_{\text {in }}-\left(\sum \dot{\mathrm{m}}_{\mathrm{i}} \mathrm{h}_{\mathrm{i}}\right)_{\text {out }}$

$0=\sum\left(1-\frac{\mathrm{T}_{0}}{\mathrm{~T}}\right) \dot{\mathrm{Q}}-\dot{\mathrm{W}}-\left(\sum \dot{\mathrm{m}}_{\mathrm{i}} \mathrm{ex}_{\mathrm{i}}\right)_{\text {in }}-\left(\sum \dot{\mathrm{m}}_{\mathrm{i}} \mathrm{ex}_{\mathrm{i}}\right)_{\text {out }}-\dot{\mathrm{I}}$

where $\dot{\mathrm{m}}$ is mass flow rate $(\mathrm{kg} / \mathrm{s})$; $\mathrm{i}$ is state point or index $\mathrm{i}$; $\dot{\mathrm{Q}}$ is thermal energy rate $(\mathrm{kW}) ; \dot{\mathrm{W}}$ is power $(\mathrm{kW}) ; \mathrm{h}$ is the specific enthalpy $(\mathrm{kJ} / \mathrm{kg}) ; \mathrm{T}_{0}$ reference temperature $(298 \mathrm{~K}) ; \mathrm{T}$ is temperature $(\mathrm{K})$; ex is specific exergy $(\mathrm{kJ} / \mathrm{kg})$; $\mathrm{I}$ is the exergy destruction rate or irreversibility $(\mathrm{kW})$.

The specific exergy Eq. (4) is composed of the physical exergy Eq. (5) and chemical exergy Eq. (6). The fuel exergy is calculated by Eq. (7) and the ratio of standard Chemical exergy and lower heating value of fuel by Eq. (8) [8].

$\mathrm{ex}=\mathrm{ex}_{\mathrm{f}}+\mathrm{ex}_{\mathrm{ch}}$

$\mathrm{ex}_{\mathrm{f}}=\left(\mathrm{h}-\mathrm{h}_{0}\right)-\mathrm{T}_{0}\left(\mathrm{~s}-\mathrm{s}_{0}\right)$

$\operatorname{ex}_{\mathrm{ch}}=\sum\left(\mathrm{x}_{\mathrm{i}} \mathrm{ex}_{\mathrm{ch,i}, 0}+\mathrm{R}_{\mathrm{i}} \mathrm{T}_{0}\left(\mathrm{y}_{\mathrm{i}} \ln \mathrm{y}_{\mathrm{i}}\right)\right)$

$\operatorname{ex}_{\text {fuel }}=\beta^{*} \mathrm{LHV}$

$\beta=1.034+0.0183\left(\frac{\mathrm{H}}{\mathrm{C}}\right)-0.064\left(\frac{1}{\mathrm{C}}\right)$

where $\mathrm{ex}_{\mathrm{f}}$ is physical exergy $(\mathrm{kJ} / \mathrm{kg})$; $\mathrm{ex}_{\mathrm{ch}}$ is chemical exergy $(\mathrm{kJ} / \mathrm{kg}) ; h_{0}$ is enthalpy in reference condition $(\mathrm{kJ} / \mathrm{kg}) ; s_{0}$ is entropy in reference condition $(\mathrm{kJ} / \mathrm{kg}-\mathrm{K})$; $\mathrm{s}$ is entropy $(\mathrm{kJ} / \mathrm{kg}-\mathrm{K})$; $\mathrm{x}_{\mathrm{i}}$ is the mass fraction of each component $\mathrm{i} ; \mathrm{y}_{\mathrm{i}}$ is the molar fraction of of each component $\mathrm{i}$; $\mathrm{ex}_{\mathrm{ch}, \mathrm{i}, 0}$ is standard chemical exergy $(\mathrm{kJ} / \mathrm{kg}) ; \mathrm{R}_{\mathrm{i}}$ is the gas constant of each component $\mathrm{i}$; $(\mathrm{kJ} / \mathrm{kg}-\mathrm{K}) ; \mathrm{H}$ is the number of hydrogen atoms in the fuel; $\mathrm{C}$ is the number of carbon atoms in the fuel.

The performance of each system is evaluated using energy efficiencies Eq. (9) and exergy efficiency Eq. (10), as well as the specific $\mathrm{CO}_{2}$ production from the natural gas combustion Eq. (11).

$\eta_{\mathrm{I}}=\frac{\mathrm{W}_{\mathrm{GT}, \text { net }}+\mathrm{W}_{\mathrm{ST}, \mathrm{Net}}}{\mathrm{m}_{\text {fuel }} \mathrm{LHV}}$

$\eta_{\text {II }}=1-\frac{I_{\text {tot }}}{m_{\text {fuel }} \text { ex }_{\text {fuel }}}$

$\mathrm{Em}_{\mathrm{CO} 2}=\frac{\mathrm{m}_{\mathrm{CO} 2 \text {,tot }}}{\mathrm{W}_{\mathrm{GT}, \mathrm{Net}}+\mathrm{W}_{\mathrm{ST}, \mathrm{Net}}}$

where $\mathrm{W}_{\mathrm{GT}, \text { net }}$ is the net power of gas turbine cycle $(\mathrm{kW}) ; \mathrm{W}_{\mathrm{ST} \text {,ne }}$ is the net power of steam cycle $(\mathrm{kW}) ; \mathrm{m}_{\text {fuel }}$ is the fuel mass flow $(\mathrm{kg} / \mathrm{s})$; LHV is the lower heating value of fuel $(\mathrm{kJ} / \mathrm{kg}) ; \mathrm{Em}_{\mathrm{CO} 2}$ specific $\mathrm{CO}_{2}$ produced in the combustion process $(\mathrm{g} / \mathrm{kWh})$; $\mathrm{m}_{\mathrm{CO} 2 \text {,tot }}$ total $\mathrm{CO}_{2}$ produced $(\mathrm{g} / \mathrm{h}), \mathrm{I}_{\text {tot }}$ is the total plant irreversibility $(\mathrm{kW})$.

\subsection{Semi-closed oxy-fuel combustion combined cycle}

The SCOC-CC is presented in Figure 1. In this cycle, $\mathrm{CO}_{2}$ (stream 1) is compressed until the combustion chamber pressure (stream 2). Then this $\mathrm{CO}_{2}$ stream, fuel (stream 6) and oxygen provided by the ASU (stream 9) are fed in the combustion chamber. The combustion products (stream 3) are expanded in the GT turbine (stream 5), and the flue gases provide heat for a steam cycle trough an HRSG. The water present in the flue gases is then removed in the dehumidifier. Then the $\mathrm{CO}_{2}$ (stream 13) is divided in two streams, about $90 \%$ of stream 13 mass flow is recycled to the gas turbine compressor (stream 16), and the other part is compressed (stream 14) and captured (stream 15).

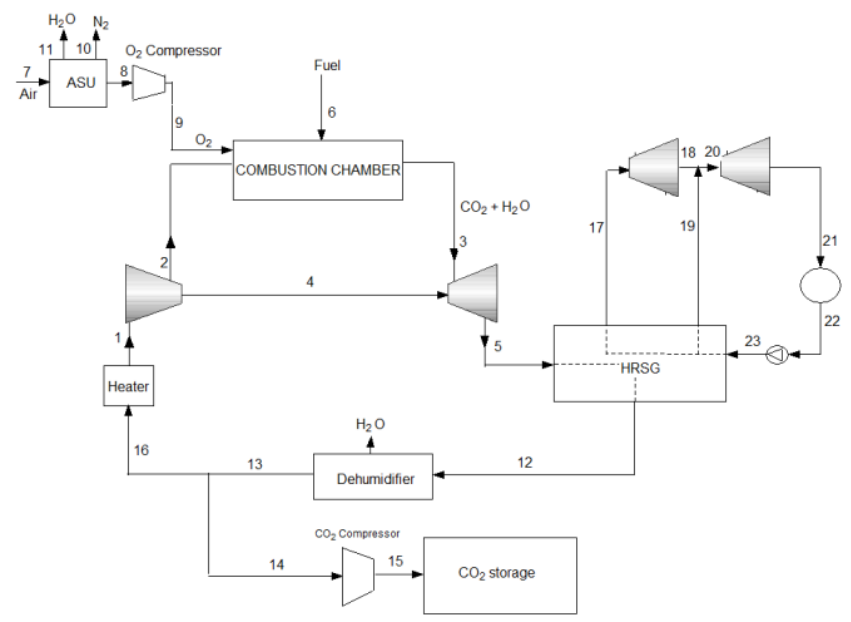

Figure 1. SCOC-CC.

The $\mathrm{O}_{2}$ purity is an important parameter for oxy-fuel combustion power plants as purer oxygen streams increase ASU energy consumption, decreasing power plant efficiency. On the other hand, an oxygen stream with low oxygen purity will produce flue gases with more impurities, and it can result in an increase in the cost and energy consumption of the $\mathrm{CO}_{2}$ treatment and compression unit [2]. $\mathrm{Hu}$ et al. [9] parameterized the specific energy consumption of ASU by cryogenic distillation as a function of oxygen purity. For oxygen purity equal or lower than 97 mol\% the Eq. (12) is used, for purities greater than 97 mol\% Eq. (13) is used. The molar composition of the oxygen stream supplied by the ASU is shown in Table 1 for different values of $\mathrm{y}_{\mathrm{O}_{2}}$. The oxygen leaves the ASU at 1.013 bar and $27^{\circ} \mathrm{C}$.

Table 1. Oxygen composition [9].

\begin{tabular}{cccccccc}
\hline $\mathbf{O}_{2}$ & $\mathbf{0 . 8 5 0}$ & $\mathbf{0 . 8 6 0}$ & $\mathbf{0 . 8 7 0}$ & $\mathbf{0 . 8 8 0}$ & $\mathbf{0 . 8 9 0}$ & $\mathbf{0 . 9 0 0}$ & $\mathbf{0 . 9 1 0}$ \\
$\mathbf{A r}$ & 0.038 & 0.038 & 0.038 & 0.039 & 0.039 & 0.039 & 0.039 \\
$\mathbf{N}_{2}$ & 0.112 & 0.102 & 0.092 & 0.081 & 0.071 & 0.061 & 0.051 \\
\hline $\mathbf{O}_{2}$ & $\mathbf{0 . 9 2 0}$ & $\mathbf{0 . 9 3 0}$ & $\mathbf{0 . 9 4 0}$ & $\mathbf{0 . 9 5 0}$ & $\mathbf{0 . 9 6 0}$ & $\mathbf{0 . 9 7 0}$ & $\mathbf{0 . 9 8 0}$ \\
$\mathbf{A r}$ & 0.040 & 0.040 & 0.041 & 0.041 & 0.040 & 0.030 & 0.020 \\
$\mathbf{N}_{\mathbf{2}}$ & 0.040 & 0.030 & 0.019 & 0.009 & 0 & 0 & 0 \\
\hline
\end{tabular}

$\mathrm{e}_{\mathrm{ASU}}=92.3103+8.2457 \mathrm{y}_{\mathrm{O}_{2}}$

$\mathrm{e}_{\mathrm{ASU}}=383.3773 /\left(100-\mathrm{y}_{\mathrm{O}_{2}}\right)^{0.4577}+660.0583$ 
where $\mathrm{e}_{\mathrm{ASU}}$ is ASU specific energy consumption $(\mathrm{kJ} / \mathrm{kg}) ; \mathrm{y}_{\mathrm{O}_{2}}$ is oxygen purity ( $\mathrm{mol} \%)$.

The isentropic and polytropic efficiencies utilized for the compressors, turbines and pumps are shown in Table 2 [11]. The isentropic efficiency is calculated by Eq. (14) for compressors and pumps and by Eq. (15) for turbines [12]. The compressions of $\mathrm{CO}_{2}$ and $\mathrm{O}_{2}$ are done in 3 stages with intercooling to reduce the compressors energy consumption, according to Figure 2. The fuel composition and LHV are presented in Table 3.

\begin{tabular}{ccc} 
Table 2. Compressors and turbines & efficiencies [11][12]. \\
\hline Equipment & $\boldsymbol{\eta}_{\text {polytropic }}$ & $\boldsymbol{\eta}_{\text {isentropic }}$ \\
\hline GT Turbine & 0.87 & - \\
GT Compressor & 0.87 & - \\
Water pumps & - & 0.75 \\
$\mathrm{CO}_{2} / \mathrm{O}_{2}$ Compressors & 0.85 & - \\
High-pressure steam turbine & - & 0.92 \\
Low-pressure steam turbine & - & 0.89 \\
\hline
\end{tabular}

$$
\begin{array}{r}
\eta_{\text {isen }}=\frac{h_{\text {out }, \text { iso }}-h_{\text {in }}}{h_{\text {out }}-h_{\text {in }}} \\
=\frac{\left(P_{\text {out }} / P_{\text {in }}\right)^{\frac{(\gamma-1)}{\gamma}}-1}{\left(P_{\text {out }} / P_{\text {in }}\right)^{\frac{\eta_{\text {pol }(\gamma-1)}^{\gamma}}{\gamma}-1}} \\
\eta_{\text {isen }}=\frac{h_{\text {in }}-h_{\text {out }}}{h_{\text {in }}-h_{\text {out }, \text { iso }}} \\
=\frac{1-\left(P_{\text {out }} / P_{\text {in }}\right)^{\frac{\eta_{\text {pol }(\gamma-1)}}{\gamma}}}{1-\left(P_{\text {out }} / P_{\text {in }}\right)^{\frac{\gamma-1}{\gamma}}}
\end{array}
$$

where $h_{\text {in }}$ is the inlet enthalpy $(\mathrm{kJ} / \mathrm{kg}) ; h_{\text {out }}$ is the outlet enthalpy $(\mathrm{kJ} / \mathrm{kg}) ; h_{\text {out } \text { iso }}$ is the outlet isentropic enthalpy $(\mathrm{kJ} / \mathrm{kg}) ; P_{\text {out }}$ is the outlet pressure (bar); $P_{\text {in }}$ is the inlet pressure (bar); $\eta_{\text {pol }}$ is the polytropic efficiency; $\gamma$ is the heat capacity ratio.

The bleed air mass flow (stream 4) needed to cool the GT turbine blades has been determined by Eq. (16) [9]

$$
\begin{aligned}
\dot{\mathrm{m}}_{\text {cooling }}=4.6 \times 10^{-8}(\mathrm{TIT}+273.15)^{2}+ \\
1.47897 \times 10^{-5}(\mathrm{TIT}+273.15)-0.06928
\end{aligned}
$$

where $\dot{\mathrm{m}}_{\text {cooling }}$ is the bleed air mass flow (kg/s); TIT is the GT turbine inlet temperature $\left({ }^{\circ} \mathrm{C}\right)$.

This study assumed that combustion is stoichiometric, and it is given by $\mathrm{Eq}$ (17). A pressure drop of $3 \%$ was assumed in the combustion chamber. The electric generators efficiency is $98.5 \%$ [13].

Table 3. Fuel composition and fuel LHV [8]

\begin{tabular}{lc}
\hline Fuel composition (mol \%) & \\
\hline $\mathrm{CH}_{4}$ & $89 \%$ \\
$\mathrm{C}_{2} \mathrm{H}_{6}$ & $7 \%$ \\
$\mathrm{C}_{3} \mathrm{H}_{8}$ & $1 \%$ \\
$\mathrm{C}_{4} \mathrm{H}_{10}$ & $0.1 \%$ \\
$\mathrm{C}_{6} \mathrm{H}_{14}$ & $0.001 \%$ \\
$\mathrm{CO}_{2}$ & $2 \%$ \\
$\mathrm{~N}_{2}$ & $0.899 \%$ \\
\hline Fuel LHV (kJ/kg) & 46480 \\
\hline
\end{tabular}

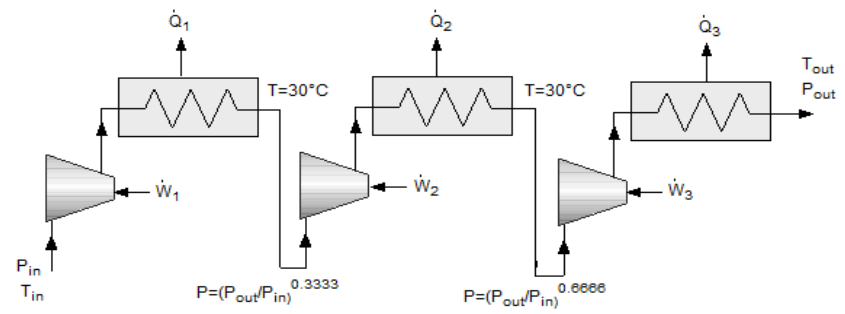

Figure 2. Compressions of $\mathrm{CO}_{2}$ and $\mathrm{O}_{2}$.

$$
\begin{aligned}
& \mathrm{C}_{\mathrm{x}} \mathrm{H}_{\mathrm{y}} \mathrm{O}_{\mathrm{z}} \mathrm{N}_{\mathrm{w}}+\mathrm{a}(\left.\mathrm{O}_{2}+\frac{\mathrm{y}_{\mathrm{N}_{2}}}{\mathrm{y}_{\mathrm{O}_{2}}} \mathrm{~N}_{2}+\frac{\mathrm{y}_{\mathrm{Ar}}}{\mathrm{y}_{\mathrm{O}_{2}}} \mathrm{Ar}\right) \\
& \rightarrow \mathrm{bN}_{2}+\mathrm{cCO}_{2}+\mathrm{dH}_{2} \mathrm{O}+\mathrm{eAr}
\end{aligned}
$$

where $\mathrm{x}, \mathrm{y}, \mathrm{z}, \mathrm{w}$ are, respectively, the number of atoms of carbon, hydrogen, oxygen and nitrogen in the fuel; a, b, c, d, e are stoichiometric coefficients; $\mathrm{y}_{\mathrm{N}_{2}}, \mathrm{y}_{\mathrm{O}_{2}}, \mathrm{y}_{\mathrm{Ar}}$ are the molar fractions of the nitrogen, oxygen and argon provided by the ASU.

The HRSG of the SOCC-CC and the CC has two pressure levels, and it consists of three heat exchangers (economizer, evaporator and superheat) for each pressure level. It was considered that the high-pressure level water is pre-heated in the low-pressure economizer, and then it is pumped to the high-pressure economizer. A pressure loss of 40 mbar was assumed on the flue gases side of the HRSG [11]; on the water/steam side, pressures losses were neglected. For HRSG design, the pinch point is between $8-20{ }^{\circ} \mathrm{C}$, and the approach point is between $5-12^{\circ} \mathrm{C}[14][15]$. For the HRSG design, it was considered an approach point of $12^{\circ} \mathrm{C}$ for low and high-pressure economizers, the pinch point of the lowpressure evaporator is $15^{\circ} \mathrm{C}$, and the high-pressure evaporator is $20^{\circ} \mathrm{C}$ [16]. In addition to the pinch and approach point, a temperature difference of $35^{\circ} \mathrm{C}$ was considered between the high-pressure steam turbine inlet temperature and the gas turbine exhaust gases on the HRSG inlet. The HRSG temperature distribution is shown in Figure 3. Table 4 presents the usual nominal temperature and pressure ranges for the HRSG.

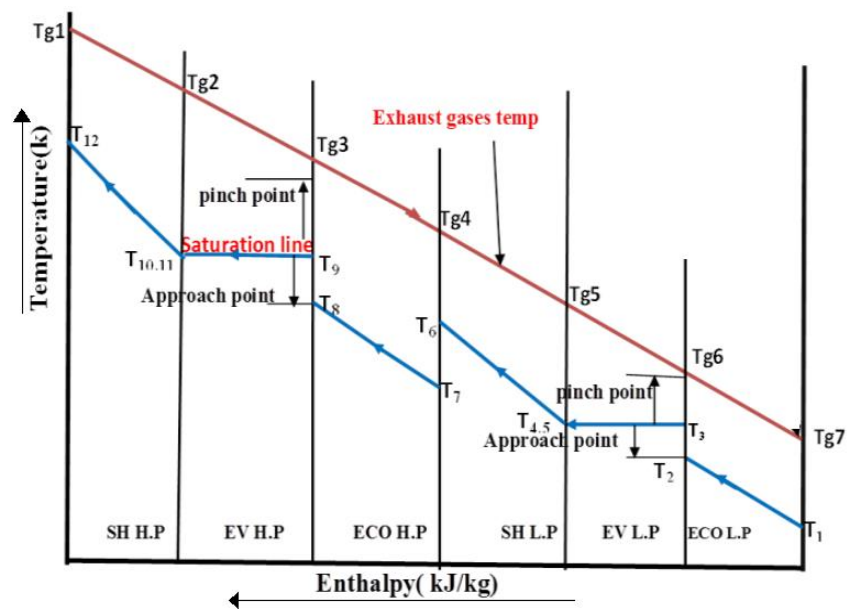

Figure 3. HRSG temperature distribution [17].

Table 4. HRSG usual operational range [18].

\begin{tabular}{ccc}
\hline High-pressure & Temperature $\left({ }^{\circ} \mathrm{C}\right)$ & $500-565$ \\
\cline { 2 - 3 } level & Pressure $($ bar $)$ & $55-85$ \\
\hline Low-pressure & Temperature $\left({ }^{\circ} \mathrm{C}\right)$ & $200-260$ \\
\cline { 2 - 3 } level & Pressure (bar) & $3-8$ \\
\hline
\end{tabular}

Flue gas water is removed in a dehumidifier, where , a pressure loss of $10 \mathrm{mbar}$ was assumed. A heater before the 
gas turbine compressor is needed to decrease the relative humidity of the $\mathrm{CO}_{2}$ stream leaving the dehumidifier, this device increases the temperature by $4^{\circ} \mathrm{C}$ [7]. The condenser, dehumidifier and intercooler compression stages are cooled with water, which enters the equipment at ambient temperature $\left(25^{\circ} \mathrm{C}\right)$ and leaves at $35^{\circ} \mathrm{C}$.

The first law efficiency of the SCOC-CC is calculated by Eq. (9), and it can also be determined in function of the input variables: dehumidifier outlet temperature $\left(\mathrm{T}_{13}\right)$, GT compressor pressure ratio (pr), GT turbine inlet temperature $\left(\mathrm{T}_{3}\right)$, fuel and oxygen temperature in the combustion chamber inlet ( $\mathrm{T}_{9}$ and $\left.\mathrm{T}_{6}\right)$, ASU oxygen purity $\left(\mathrm{y}_{\mathrm{O}_{2} \mathrm{ASU}}\right)$, lowpressure steam turbine inlet pressure $\left(\mathrm{p}_{20}\right)$, high-pressure steam turbine inlet pressure $\left(\mathrm{p}_{17}\right)$, condenser pressure $\left(\mathrm{p}_{21}\right)$.

The GT compressor pressure ratio for SCOC-CC is in the range of 30-40 [16]. According to [19], the GT turbine inlet temperature can reach temperatures in the range of $1500^{\circ} \mathrm{C}$ for modern conventional gas turbines. The condenser pressure is 0.088bar [20]. It was considered that the dehumidifier outlet temperature should be in the range of 27 $55^{\circ} \mathrm{C}$, and fuel and oxygen temperature are $30^{\circ} \mathrm{C}$ in the combustion chamber inlet.

From the operational limits of the SCOC-CC, it is possible to formulate an optimization problem to maximize the energetic/first law efficiency:

Maximize: $\eta_{\mathrm{I}}=\eta_{\mathrm{I}}\left(\mathrm{T}_{13}, \mathrm{pr}, \mathrm{T}_{3}, \mathrm{y}_{\mathrm{O} 2 \mathrm{ASU}}, \mathrm{p}_{20}, \mathrm{p}_{17}\right)$ Subject to:

$$
\left\{\begin{array}{c}
27 \leq \mathrm{T}_{13} \leq 55 \\
30 \leq \mathrm{pr} \leq 40 \\
1050 \leq \mathrm{T}_{3} \leq 1500 \\
0.8 \leq \mathrm{y}_{\mathrm{O} 2 \mathrm{ASU}} \leq 0.995 \\
3 \leq \mathrm{p}_{20} \leq 8 \\
55 \leq \mathrm{p}_{17} \leq 85 \\
200 \leq \mathrm{T}_{20} \leq 260 \\
500 \leq \mathrm{T}_{17} \leq 565
\end{array}\right.
$$

where the temperatures and pressures are indexed accordingly to Figure 1.

\subsection{Conventional combined cycle}

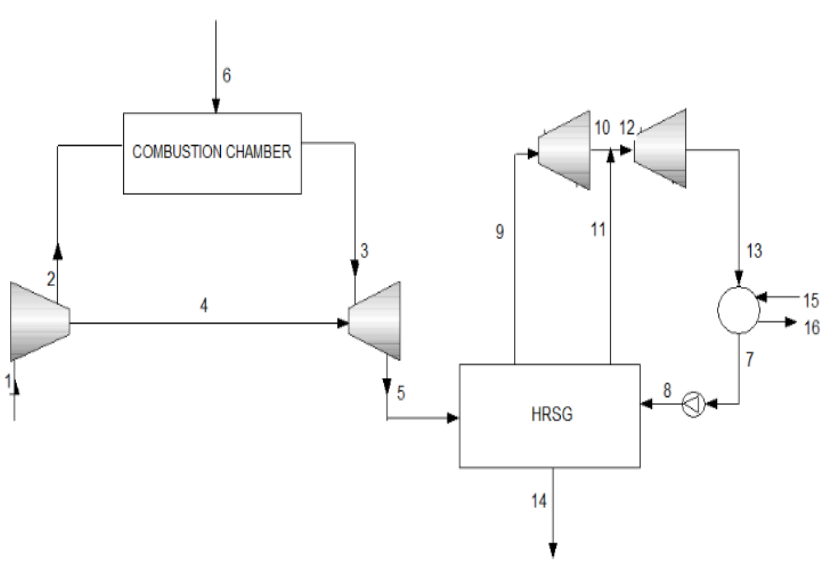

Figure 4. Combined cycle.

Figure 4 shows the conventional combined cycle. The same thermodynamic assumptions were utilized in the CC model. The gas turbine working fluid is air, which enters the GT compressor (stream 1) at $25^{\circ} \mathrm{C}, 1.013$ bar, and relative humidity of $60 \%$, the air is compressed until the combustion chamber pressure (stream 2) and the air and fuel are fed in the combustion chamber. The combustion was also considered stoichiometric, and it is given by Eq. (18). The flue gases (stream 3) are expanded in the GT turbine (stream 5), and after the expansion, the flue gases provide heat for a steam cycle trough an HRSG and are released into the atmosphere (stream 14).

$$
\begin{aligned}
\mathrm{C}_{\mathrm{x}} \mathrm{H}_{\mathrm{y}} \mathrm{O}_{\mathrm{z}} \mathrm{N}_{\mathrm{w}}+\mathrm{a}\left(\mathrm{O}_{2}+3.74 \mathrm{~N}_{2}+0.04 \mathrm{Ar}+0.0033 \mathrm{CO}_{2}\right. \\
\left.+0.0923 \mathrm{H}_{2} \mathrm{O}\right) \\
\rightarrow \mathrm{bN}_{2}+\mathrm{cCO}_{2}+\mathrm{dH}_{2} \mathrm{O}+\mathrm{eAr}
\end{aligned}
$$

where $\mathrm{x}, \mathrm{y}, \mathrm{z}, \mathrm{w}$ are, respectively, the number of atoms of carbon, hydrogen, oxygen and nitrogen in the fuel; a, b, c, d, e are stoichiometric coefficients.

For the comparative analysis, the CC GT turbine inlet temperature is the same as the SCOC-CC. The pressure ratio for conventional gas turbines is usually in the range of 5-30 [20]. The following optimization problem finds the optimal efficiency of the conventional $\mathrm{CC}$ :

Maximize: $\eta_{\mathrm{I}}=\eta_{\mathrm{I}}\left(\mathrm{pr}, \mathrm{p}_{9}, \mathrm{p}_{12}\right)$

Subject to:

$$
\left\{\begin{array}{c}
5 \leq \mathrm{pr} \leq 30 \\
3 \leq \mathrm{p}_{12} \leq 8 \\
55 \leq \mathrm{p}_{9} \leq 85 \\
200 \leq \mathrm{T}_{12} \leq 260 \\
500 \leq \mathrm{T}_{9} \leq 565
\end{array}\right.
$$

where the temperatures and pressures are indexed accordingly to Figure 4.

\subsection{Particle swarm optimization}

The optimization problems were solved by particle swarm optimization (PSO). PSO is an optimization algorithm for the solution of nonlinear and linear functions created by [21]. It was inspired by the intelligent behaviour of groups of animals such as swarms, shoals and flocks of birds. PSO is a search technique based on the social behaviour of individuals. This behaviour initially presents a random and disordered search, but an organization in the flight is observed over time, and a search pattern is presented. When the search target is reached, all particles tend to go towards the objective [22].

The PSO population is initialized randomly, over time, the position of the particles is updated based on preestablished rules. The position and velocity of each particle $i$ at the iteration $(t+1)$, respectively, are given by Eq. (19) and Eq. (20), respectively. Although there are several proposals for the weight of inertia $(w)$, in this work, the weight of inertia by linear decrease is used (Eq. 21) [23].

$$
\begin{aligned}
& x_{i}(t+1)=x_{i}(t)+v_{i}(t+1) \\
& \mathrm{v}_{\mathrm{i}}(\mathrm{t}+1)=\mathrm{wv}_{\mathrm{i}}(\mathrm{t})+\mathrm{c}_{1} \mathrm{r}_{1}\left(\mathrm{P}_{\text {best-i }}(\mathrm{t})-\mathrm{x}_{\mathrm{i}}(\mathrm{t})\right) \\
& +c_{2} r_{2}\left(G_{\text {best }}(t)-x_{i}(t)\right) \\
& \mathrm{w}(\mathrm{t})=\mathrm{w}_{\max }-\frac{\mathrm{w}_{\max }-\mathrm{w}_{\min }}{\mathrm{t}_{\max }} \mathrm{t}
\end{aligned}
$$

where $\mathrm{w}$ is the weight of inertia, $\mathrm{r}_{1}$ and $\mathrm{r}_{2}$ are random independent variables between 0 and $1, P_{\text {best- } i}$ is the best position found by the particle $i, G_{\text {best }}$ the best position found by the swarm, $c_{1}$ and $c_{2}$ are learning parameters, $t_{\max }$ is the maximum number of iterations, $w_{\max }$ is the maximum weight of inertia, $\mathrm{w}_{\min }$ is the minimum weight of inertia. 
Table 5 shows the PSO parameters. [24] presented the effect of the number of particles in the swarm for several optimization problems and concluded that 30 particles provide a good trade-off between robustness and speed of convergence. The other parameters of the PSO were obtained from [25] and [23].

Table 5. PSO parameters.

\begin{tabular}{ccccccc}
\hline $\mathrm{c}_{1}$ & $\mathrm{c}_{2}$ & $\begin{array}{c}\text { Maximum } \\
\text { Velocity }\end{array}$ & $\begin{array}{c}\text { Number of } \\
\text { particles }\end{array}$ & $\begin{array}{c}\text { Number } \\
\text { of } \\
\text { iterations }\end{array}$ & $\mathrm{w}_{\max }$ & $\mathrm{w}_{\min }$ \\
\hline 1.5 & 2.5 & 4 & 30 & 300 & 0.9 & 0.4 \\
\hline
\end{tabular}

\section{Results}

The computacional models of both thermodynamic cycles were validated utilizing the same computacional assumptions as [11]. The first law efficiency obtained for the SCOC-CC in [11] is $47 \%$, in this work, with the same computacional assumptions of [11] an efficiency of $48.28 \%$ was obtained, which represents a deviation of $2.74 \%$. For the CC case, [11] obtained a first law efficiency of $57 \%$ and in this work an efficiency of $57.74 \%$ was obtained, representing a deviation of $1.3 \%$. Considering that different softwares were used for the thermodynamic models development, the difference in the efficiencies obtained is acceptable. In this work, EES was used for the computacional models development and [11] developed their computacional models with SimSCI PRO/II.

Applying the PSO algorithm, the optimal operational points from Table 6 were obtained. The optimization utilizing the ASU model from [9] found that the optimal ASU oxygen purity (yozAsu) for the SCOC-CC is 95.99 mol\%. The SCOC-CC optimal pressure ratio is 40 , which is the maximum value from the optimization problem. The SCOC-CC pressure ratio is 3.28 times the $\mathrm{CC}$ pressure ratio; this big difference occurs due to the change in the working fluid. Figure 5 shows the variation of the heat capacity ratio ( $\gamma$ ) with the temperature of the GT compressor and GT turbine working fluid of the SCOC-CC and CC. It is noticed that the heat capacity ratio is lower in the SCOC-CC compressor and turbine than in the $\mathrm{CC}$ case. For this reason, a higher pressure ratio is needed in the SCOC-CC to obtain a similar temperature drop as in the CC. In this way, the influence of the heat capacity ratio is the main reason for the higher-pressure ratio needed in the SCOC-CC.

Table 6. PSO optimization results.

\begin{tabular}{ccccccc}
\hline & $\begin{array}{c}\mathrm{T}_{13} \\
\left({ }^{\circ} \mathrm{C}\right)\end{array}$ & $\mathrm{pr}$ & $\begin{array}{c}\mathrm{T}_{3} \\
\left({ }^{\circ} \mathrm{C}\right)\end{array}$ & $\begin{array}{c}\mathrm{y}_{\mathrm{O} 2 \mathrm{ASU}} \\
(\mathrm{mol} \%)\end{array}$ & $\begin{array}{c}\mathrm{p}_{19} \\
(\mathrm{bar})\end{array}$ & $\begin{array}{c}\mathrm{p}_{17} \\
(\mathrm{bar})\end{array}$ \\
\hline SCOC-CC & 33.017 & 40 & 1223 & 95.99 & 5.71 & 85 \\
\hline & - & $\mathrm{pr}$ & $\mathrm{T}_{3}$ & - & $\mathrm{p}_{12}$ & $\mathrm{p}_{9}$ \\
& & & $\left({ }^{\circ} \mathrm{C}\right)$ & & (bar) & (bar) \\
\hline $\mathrm{CC}$ & - & 12.18 & 1223 & - & 5.93 & 85 \\
\hline
\end{tabular}

The SCOC-CC efficiency obtained from the optimal point is $45.55 \%$. The properties of each stream of the SCOC$\mathrm{CC}$ at the optimal point and considering a fuel consumption of $1 \mathrm{~kg} / \mathrm{s}$ are presented in Table 7, and the mass composition of each stream is shown in Table 8 , the streams are numbered accordingly to Figure 1.

The CC efficiency obtained from the optimal point is $52.51 \%$. The properties of each stream of the CC at the optimal point and considering a fuel consumption of $1 \mathrm{~kg} / \mathrm{s}$ are presented in Table 9, and the mass composition of each stream is shown in Table 10, the streams are numbered accordingly to Figure 4.

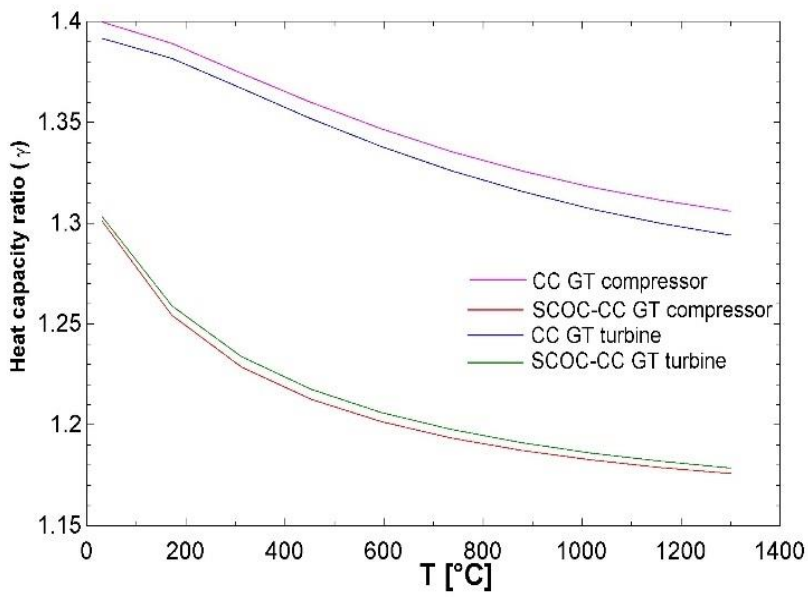

Figure 5. Heat capacity ratio in the GT turbine and GT compressor.

Table 7. SCOC-CC: Properties of each stream.

\begin{tabular}{ccccccc}
\hline & $\begin{array}{c}\text { Mass } \\
\text { flow }\end{array}$ & $\begin{array}{c}\text { Pressure } \\
\text { (bar) }\end{array}$ & $\begin{array}{c}\text { Tempe- } \\
\text { rature } \\
\left({ }^{\circ} \mathbf{C}\right)\end{array}$ & $\begin{array}{c}\text { Enthalpy } \\
(\mathbf{k J} / \mathbf{k g})\end{array}$ & $\begin{array}{c}\text { Entropy } \\
(\mathbf{k J} / \mathbf{k g . K})\end{array}$ & $\begin{array}{c}\text { Exergy } \\
(\mathbf{k J} / \mathbf{k g})\end{array}$ \\
\hline 1 & 42.6 & 1.013 & 37.02 & -8433 & 4.942 & 0.2004 \\
2 & 40.4 & 40.52 & 450.8 & -8017 & 5.055 & 382.2 \\
3 & 45.35 & 39.71 & 1223 & -7234 & 6.217 & 1112 \\
4 & 2.196 & 40.52 & 450.8 & -8017 & 5.055 & 382.2 \\
5 & 47.55 & 1.063 & 600.2 & -8032 & 6.261 & 287.1 \\
6 & 1.00 & 40.52 & 30.0 & & & 48938 \\
7 & 17.15 & 1.013 & 25.0 & -158 & 6.745 & 0 \\
8 & 3.945 & 1.013 & 27.0 & 1.789 & 6.288 & 0.00597 \\
9 & 3.945 & 40.52 & 30.0 & 4.475 & 5.348 & 283 \\
10 & 13.01 & 1.013 & 27.0 & 2.072 & 6.834 & 0.00790 \\
11 & 0.202 & 1.013 & 27.0 & 113.2 & 0.3949 & 0.02794 \\
12 & 47.55 & 1.023 & 95.72 & -8588 & 5.336 & 0.6009 \\
13 & 45.54 & 1.013 & 33.02 & & & \\
14 & 2.943 & 1.013 & 33.02 & -8436 & 4.931 & 0.0897 \\
15 & 2.943 & 100 & 30.0 & -8439 & 4.023 & 268.3 \\
16 & 42.6 & 1.013 & 33.02 & -8436 & 4.931 & 0.0897 \\
17 & 6.997 & 85 & 565 & 3553 & 6.889 & 1503 \\
18 & 6.997 & 5.712 & 205.8 & 2864 & 7.017 & 776.1 \\
19 & 1.297 & 5.712 & 195 & 2840 & 6.968 & 767.4 \\
20 & 8.294 & 5.712 & 204.1 & 2860 & 7.01 & 774.7 \\
21 & 8.294 & 0.0888 & 43.51 & 2278 & 7.237 & 124.7 \\
22 & 8.294 & 0.0888 & 43.51 & 182.2 & 0.6189 & 2.216 \\
23 & 8.294 & 5.712 & 43.58 & 183 & 0.6195 & 2.795 \\
\hline & & & & & & \\
\hline
\end{tabular}

Table 8. SCOC-CC: Mass composition of each stream.

\begin{tabular}{|c|c|c|c|c|c|}
\hline$\#$ & $\mathrm{x}_{\mathrm{CO}_{2}}(\%)$ & $\mathrm{x}_{\mathrm{O}_{2}}(\%)$ & $\mathrm{x}_{\mathrm{Ar}}(\%)$ & $\mathbf{x}_{\mathrm{H}_{2} \mathrm{O}}(\%)$ & $\mathrm{x}_{\mathrm{N}_{2}}(\%)$ \\
\hline 1 & 91.26 & - & 6.627 & 2.112 & 0.001 \\
\hline 2 & 91.26 & - & 6.627 & 2.112 & 0.001 \\
\hline 3 & 87.23 & - & 6.335 & 6.432 & 0.001 \\
\hline 4 & 91.26 & - & 6.627 & 2.112 & 0.001 \\
\hline 5 & 87.42 & - & 6.348 & 6.233 & 0.001 \\
\hline 6 & - & - & - & - & - \\
\hline 7 & - & 21.86 & 1.365 & 1.177 & 75.6 \\
\hline 8 & - & 95.05 & 4.945 & - & 0.001 \\
\hline 9 & - & 95.05 & 4.945 & - & 0.001 \\
\hline 10 & - & - & 0.300 & - & 99.7 \\
\hline 11 & - & - & - & 100 & - \\
\hline 12 & 87.42 & - & 6.348 & 6.233 & 0.001 \\
\hline 13 & 91.26 & - & 6.627 & 2.112 & 0.001 \\
\hline 14 & 91.26 & - & 6.627 & 2.112 & 0.001 \\
\hline 15 & 91.26 & - & 6.627 & 2.112 & 0.001 \\
\hline 16 & 91.26 & - & 6.627 & 2.112 & 0.001 \\
\hline 17 & - & - & - & 100 & - \\
\hline 18 & - & - & - & 100 & - \\
\hline 19 & - & - & - & 100 & - \\
\hline 20 & - & - & - & 100 & - \\
\hline 21 & - & - & - & 100 & - \\
\hline 22 & - & - & - & 100 & - \\
\hline 23 & - & - & - & 100 & - \\
\hline
\end{tabular}


Table 9. CC: Properties of each stream.

\begin{tabular}{ccccccc}
\hline & $\begin{array}{c}\text { Mass } \\
\text { flow } \\
\text { \# }\end{array}$ & $\begin{array}{c}\text { Pressure } \\
(\mathbf{b a r})\end{array}$ & $\begin{array}{c}\text { Tempe- } \\
\text { rature } \\
\left({ }^{\circ} \mathbf{C}\right)\end{array}$ & $\begin{array}{c}\text { Enthalpy } \\
(\mathbf{k J} / \mathbf{k g})\end{array}$ & $\begin{array}{c}\text { Entropy } \\
(\mathbf{k J} / \mathbf{k g . K})\end{array}$ & $\begin{array}{c}\mathbf{E x e r g y} \\
(\mathbf{k J} / \mathbf{k g})\end{array}$ \\
\hline 1 & 44.01 & 1.013 & 25 & -169.2 & 6.741 & 0 \\
2 & 41.74 & 12.33 & 391 & 212.1 & 6.85 & 349 \\
3 & 42.74 & 12.09 & 1223 & 46.28 & 7.959 & 1085 \\
4 & 2.26 & 12.33 & 391 & 212.1 & 6.85 & 349 \\
5 & 45.01 & 1.053 & 600 & -675.5 & 7.999 & 290.5 \\
6 & 1.00 & 12.33 & 30 & & & 48938 \\
7 & 7.91 & 0.088 & 43.5 & 182.2 & 0.6189 & 2.216 \\
8 & 7.91 & 5.93 & 43.5 & 183 & 0.6195 & 2.817 \\
9 & 6.56 & 85.00 & 565 & 3553 & 6.889 & 1503 \\
10 & 6.56 & 5.93 & 209.6 & 2871 & 7.016 & 783.8 \\
11 & 1.35 & 5.93 & 198.9 & 2848 & 6.967 & 775.1 \\
12 & 7.91 & 5.93 & 207.8 & 2867 & 7.007 & 782.3 \\
13 & 7.91 & 0.088 & 43.5 & 2278 & 7.237 & 124.7 \\
14 & 45.00 & 1.013 & 102 & -1234 & 7.07 & 9.006 \\
\hline
\end{tabular}

Table 10. CC: Mass composition of each stream.

\begin{tabular}{cccccc}
\hline$\#$ & $\mathbf{x}_{\mathbf{C O}_{2}}(\boldsymbol{\%})$ & $\mathbf{x}_{\mathbf{O}_{2}}(\boldsymbol{\%})$ & $\mathbf{x}_{\mathbf{A r}}(\boldsymbol{\%})$ & $\mathbf{x}_{\mathbf{H}_{2} \mathbf{O}} \mathbf{( \% )}$ & $\mathbf{x}_{\mathbf{N}_{2}}(\boldsymbol{\%})$ \\
\hline 1 & 0.105 & 22.92 & 1.27 & 1.19 & 74.52 \\
2 & 0.105 & 22.92 & 1.27 & 1.19 & 74.52 \\
3 & 6.388 & 13.58 & 1.24 & 5.99 & 72.78 \\
4 & 0.105 & 22.92 & 1.27 & 1.19 & 74.52 \\
5 & 6.074 & 14.05 & 1.24 & 5.59 & 72.88 \\
6 & - & - & - & - & - \\
7 & - & - & - & 100 & - \\
8 & - & - & - & 100 & - \\
9 & - & - & - & 100 & - \\
10 & - & - & - & 100 & - \\
11 & - & - & - & 100 & - \\
12 & - & - & - & 100 & - \\
13 & - & - & - & 100 & - \\
14 & 6.074 & 14.05 & 1.24 & 5.57 & 72.88 \\
\hline
\end{tabular}

From Tables 7 to 10 , some characteristics of the SCOC$\mathrm{CC}$ and $\mathrm{CC}$ can be observed:

- The SCOC-CC combustion chamber needs 3.945 $\mathrm{kg} / \mathrm{s}$ of oxygen (stream 9 - Figure 1) to burn $1 \mathrm{~kg} / \mathrm{s}$ of fuel, corresponding to $8.5 \%$ of the GT compressor inlet mass flow (stream 1 - Figure 1).

- $\quad 94 \%$ of the SCOC-CC GT exhaust gases (stream 13-Figure 1) are recirculated to the GT compressor. In pipeline transport, $\mathrm{CO}_{2}$ will be transported at supercritical pressure in the range of $80-150$ bar [6]. The remaining $6 \%$ (stream 14 and 15 - Figure 1) are compressed to 100 bar in the $\mathrm{CO}_{2}$ compressor in this work.

- Oxy-fuel GT turbine exhaust mass flow (stream 5Figure 1) is $5 \%$ greater than CC GT, which results in more steam circulating in the Rankine/bottoming cycle.

- The optimal pressure ratio for both cycles corresponds to the maximum GT turbine exhaust temperature allowed $\left(600^{\circ} \mathrm{C}\right)$. Since a temperature difference of $35^{\circ} \mathrm{C}$ was considered between the high-pressure (HP) steam turbine inlet temperature and the GT exhaust gases on the HRSG inlet. The maximum temperature allowed at the HP steam turbine inlet is $565^{\circ} \mathrm{C}$.

The power consumed (-) or produced (+) from each device are shown in Table 11. The SCOC-CC gross power is $45897 \mathrm{~kW}$ against $41982 \mathrm{~kW}$ of the CC cycle. The ASU, $\mathrm{O}_{2}$ and $\mathrm{CO}_{2}$ compressor represent together a power consumption of $13.5 \%$ from the $45897-\mathrm{kW}$ of gross power; considering the equipment needed for oxy-fuel combustion, the SCOC-CC net power is $13.2 \%$ lower than the $\mathrm{CC}$ net power.

As mentioned before, the condensers, dehumidifier and intercooler stages are cooled with water. Table 12 shows the heat removed from each device and the quantity of water for cooling.
Table 11. Power consumption.

\begin{tabular}{lcc}
\hline & SCOC-CC & CC \\
\hline Equipment & Power $(\mathbf{k W})$ & Power $(\mathbf{k W})$ \\
\hline GT Compressor & -17706 & -16778 \\
GT Turbine & 36249 & 32851 \\
\hline GT Net Power & 18543 & 15832 \\
\hline LP Pump & -6.29 & -6.22 \\
LP Steam Turbine & 4830 & 4661 \\
HP Pump & -80.09 & -74.97 \\
HP Steam Turbine & 4818 & 4470 \\
\hline Steam Cycle Net Power & 9561 & 9050 \\
\hline ASU & -3314 & - \\
$\mathrm{O}_{2}$ Compressor & -1695 & - \\
CO ${ }_{2}$ Compressor & -1200 & - \\
\hline Global Net Power & 21473 & 24745 \\
\hline
\end{tabular}

Table 12. Water consumption.

\begin{tabular}{lcc}
\hline SCOC-CC & $\begin{array}{c}\text { Heat } \\
\text { Equipment }\end{array}$ & $\begin{array}{c}\text { Cooling Water } \\
(\mathrm{kg} / \mathrm{s})\end{array}$ \\
\hline Condenser & -17381 & 415.5 \\
Dehumidifier & -7588 & 181.5 \\
$\mathrm{CO}_{2}$ Compressor intercooled stages & -1208 & 40.26 \\
$\mathrm{O}_{2}$ Compressor intercooled stages & -1684 & 28.87 \\
\hline Total & -29501 & 666.2 \\
\hline $\mathbf{C C}$ & Heat & $\begin{array}{c}\text { Cooling Water } \\
(\mathrm{kg} / \mathrm{s})\end{array}$ \\
Equipment & $(\mathrm{kW})$ & 396.4 \\
\hline Condenser & -16581 & - \\
Dehumidifier & - & - \\
$\mathrm{CO}_{2}$ Compressor intercooler stages & - & - \\
$\mathrm{O}_{2}$ Compressor intercooler stages & - & 396.4 \\
\hline Total & -16581 & \\
\hline
\end{tabular}

It is noticed that the water consumption of the SCOC-CC is much higher than the $\mathrm{CC}$ consumption since the SCOC$\mathrm{CC}$ has more components that need cooling and more steam flows through its bottoming cycle.

For the irreversibilities of each cycle components, an exergetic analysis was performed. Table 13 shows the exergy fuel and product, irreversibility and second law efficiency of the SCOC-CC components. The second law efficiency of the components is given by Eq. 22 .

$\eta_{\mathrm{II}}=\frac{\text { Prod }}{\text { Fuel }}$

where Prod is the exergy product $(\mathrm{kW})$, Fuel is the exergy fuel $(\mathrm{kW})$.

From Table 13, it is observed that the SCOC-CC second law efficiency is $45.67 \%$. It is highlighted that the oxygen production in the ASU is very irreversible, and the ASU second law efficiency is $0.004 \%$. Figure 6 shows the contribution of each piece of equipment to the global irreversibility of the plant. The most irreversible components of the SCOC-CC are the Combustion chamber, ASU, HRSG, GT compressor and GT turbine. The ASU, heater, dehumidifier, $\mathrm{CO}_{2}$ and $\mathrm{O}_{2}$ compressors combined correspond to $16.43 \%$ of the total SCOC-CC irreversibilities.

Table 14 shows the exergy fuel, exergy product, irreversibility and second law efficiency of the $\mathrm{CC}$ components. The $\mathrm{CC}$ second law efficiency is $52.2 \%$, which is $6.5 \%$ greater than the SCOC-CC. 
Table 13. SCOC-CC: Components Irreversibility.

\begin{tabular}{lcccc}
\hline \multicolumn{1}{c}{ Equipment } & $\begin{array}{c}\text { Fuel } \\
(\mathbf{k W})\end{array}$ & $\begin{array}{c}\text { Product } \\
(\mathbf{k W})\end{array}$ & $\begin{array}{c}\text { Irreversibility } \\
(\mathbf{k W})\end{array}$ & $\begin{array}{c}\boldsymbol{\eta}_{\text {II }} \\
(\boldsymbol{\%})\end{array}$ \\
\hline GT Compressor & 17706 & 16272 & 1434 & 91.9 \\
Combustion Chamber & 48938 & 33875 & 15063 & 69.2 \\
GT Turbine & 37624 & 36249 & 1375 & 96.3 \\
GT Generator & 18543 & 18265 & 278.1 & 98.5 \\
HRSG & 13620 & 11489 & 2131 & 84.4 \\
HP ST & 5087 & 4818 & 269.1 & 94.7 \\
HP ST Generator & 4818 & 4745 & 72.27 & 98.5 \\
LP ST & 5391 & 4830 & 560.5 & 89.6 \\
LP ST Generator & 4830 & 4758 & 72.45 & 98.5 \\
Condenser & 1016 & 285.1 & 731 & 28.1 \\
LP Water pump & 6.293 & 4.799 & 1.494 & 76.3 \\
HP Water pump & 80.09 & 78.05 & 2.035 & 97.5 \\
Dehumidifier & 888.4 & 124.6 & 763.8 & 14.1 \\
Heater & 5.626 & 4.716 & 0.9094 & 83.8 \\
ASU & 3314 & 0.132 & 3314 & 0.004 \\
$\mathrm{O}_{2}$ Compressor & 1783 & 1493 & 290.3 & 83.7 \\
CO Compressor & 1284 & 1056 & 227.8 & 82.3 \\
Global & & & 26,586 & 45.7 \\
\hline *HP ST= High-pressure steam turbine, LP ST= Low-pressure steam turbine
\end{tabular}

*HP ST= High-pressure steam turbine, LP ST= Low-pressure steam turbine

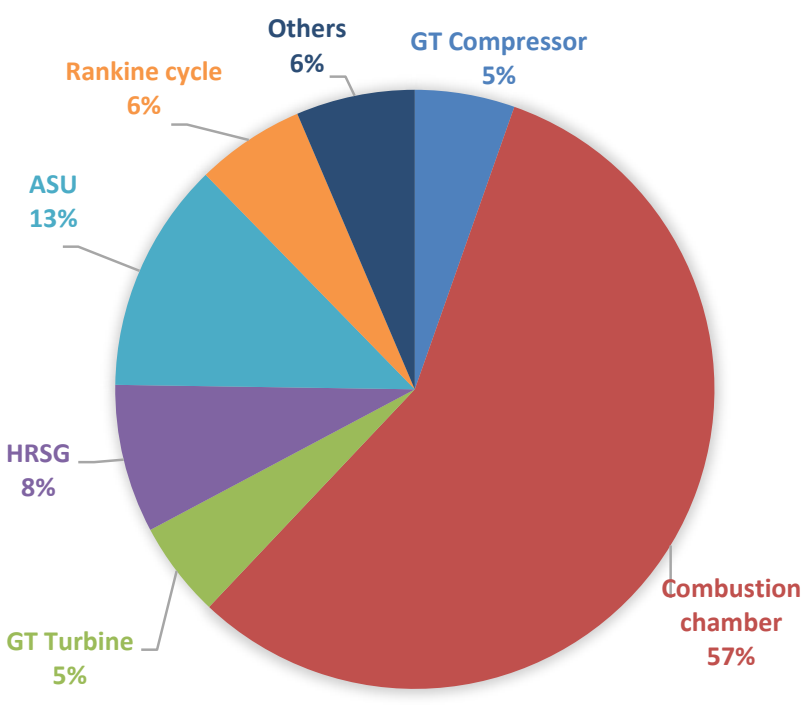

Figure 6. SCOC-CC: Irreversibilities.

Figure 7 are shown the contribution of each piece of equipment to the global irreversibility of the $\mathrm{CC}$. The most irreversible components are the combustion chamber, HRSG, GT compressor and GT turbine. The global irreversibility of the SCOC-CC is $26586 \mathrm{~kW}$ against 23394 $\mathrm{kW}$ of the CC.

The GT turbine, GT compressor and steam turbines irreversibility are smaller in the $\mathrm{CC}$ cycle. In contrast, the combustion chamber of the $\mathrm{CC}$ cycle is more irreversible than the SCOC-CC combustion chamber.

Table 14. CC: Components Irreversibility.

\begin{tabular}{lcccc}
\hline \multicolumn{1}{c}{ Equipment } & $\begin{array}{c}\text { Fuel } \\
(\mathbf{k W})\end{array}$ & $\begin{array}{c}\text { Product } \\
(\mathbf{k W})\end{array}$ & $\begin{array}{c}\text { Irreversibility } \\
(\mathbf{k W})\end{array}$ & $\begin{array}{c}\boldsymbol{\eta}_{\text {II }} \\
(\boldsymbol{\%})\end{array}$ \\
\hline GT Compressor & 16778 & 15355 & 1423 & 91.5 \\
Combustion Chamber & 48938 & 31811 & 17127 & 65.0 \\
GT Turbine & 34094 & 32851 & 1243 & 96.3 \\
GT Generator & 16073 & 15832 & 241.1 & 98.5 \\
HRSG & 12668 & 10886 & 1782 & 85.9 \\
HP ST & 4717 & 4470 & 247.1 & 94.8 \\
HP ST Generator & 4470 & 4403 & 67.05 & 98.5 \\
LP ST & 5212 & 4669 & 543.6 & 89.6 \\
LP ST Generator & 4669 & 4599 & 70.03 & 98.5 \\
Condensator & 906.9 & 272 & 634.9 & 29.9 \\
LP Water pump & 6.219 & 4.755 & 1.465 & 76.4 \\
HP Water pump & 74.97 & 61.69 & 13.28 & 82.3 \\
Global & & & 23394 & 52.2 \\
*HP ST= High-pressure steam turbine, LP ST= Low-pressure steam turbine
\end{tabular}

The SCOC-CC specific $\mathrm{CO}_{2}$ production is $450 \mathrm{~g}$ $\mathrm{CO}_{2} / \mathrm{kWh}$, and theoretically, $100 \%$ of the produced $\mathrm{CO}_{2}$ is captured. The $\mathrm{CC}$ produces $390 \mathrm{~g}-\mathrm{CO}_{2} / \mathrm{kWh}$ and all the $\mathrm{CO}_{2}$ produced is emitted to the atmosphere. Ferrari et al. [26] obtained a specific $\mathrm{CO}_{2}$ production of $416 \mathrm{~g}-\mathrm{CO}_{2} / \mathrm{kWh}$ and $90 \%$ of the $\mathrm{CO}_{2}$ produced is captured. Ferrari et al. [26] reference $\mathrm{CC}$ emits $348 \mathrm{~g}-\mathrm{CO}_{2} / \mathrm{kWh}$. The specific $\mathrm{CO}_{2}$ productions obtained in this paper are higher mainly because [26] considered higher TIT $\left(1352^{\circ} \mathrm{C}\right)$, pressure ratio $(45)$ and turbine exhaust temperature $\left(620^{\circ} \mathrm{C}\right)$. Although the SCOC$\mathrm{CC}$ specific $\mathrm{CO}_{2}$ production in this study and [26] is about $60-70 \mathrm{~g}-\mathrm{CO}_{2} / \mathrm{kWh}$ higher than the $\mathrm{CC}$.

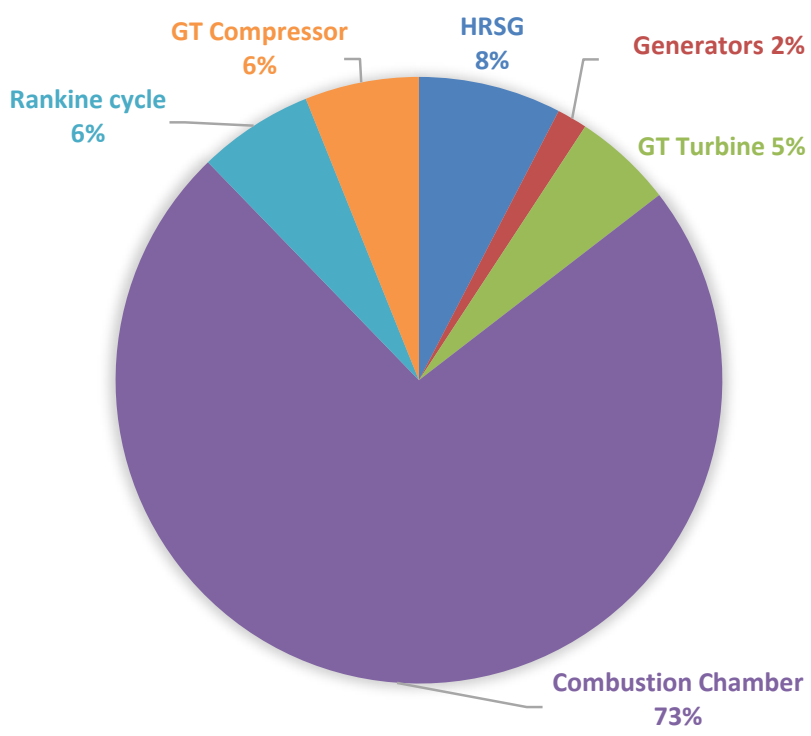

Figure 7. CC: Irreversibilities.

The captured $\mathrm{CO}_{2}$ can be injected and stored into deep saline aquifers or depleted oil and gas reservoirs or it also be used to enchance recovery of valuable fossil fuels (oil, gas and coalbed methane) [6]. The captured $\mathrm{CO}_{2}$ can be also used in beverage, medical and food processing industries, however low tolerances of various impurities and $\mathrm{CO}_{2}$ purity of at least 99.9 vol\% are needed in these industries. To achieve higher $\mathrm{CO}_{2}$ purities, $\mathrm{CO}_{2}$ purification units should be installed in the plant [2].

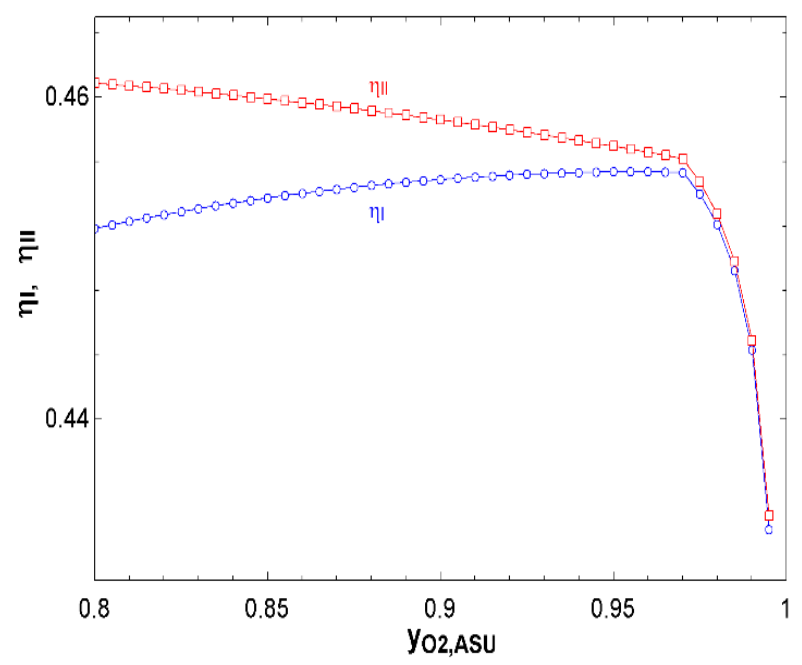

Figure 8. First and second law efficiency vs $\mathrm{O}_{2}$ purity. 
Figure 8 shows the first law efficiency, second law efficiency as a function of the ASU oxygen purity. The first law efficiency increases until the optimal oxygen purity found utilizing the PSO algorithm (95.99\%), and after the optimal point (yO2ASU $>0.9599$ ), the first law efficiency starts to decrease. The second law efficiency decreases when the oxygen purity is increased since the ASU second law efficiency is small; thus, increasing $\mathrm{O}_{2}$ purity also increases the ASU energy consumption and irreversibility.

\section{Conclusion}

The SCOC-CC first law efficiency was found through the particle swarm optimization algorithm, and its optimal first law efficiency is $45.55 \%$, representing a first law efficiency penalty of $6.96 \%$ in comparison to $\mathrm{CC}$. The $\mathrm{ASU}, \mathrm{CO}_{2}$ and $\mathrm{O}_{2}$ consume $13.5 \%$ of the SCOC-CC gross power, and the optimal oxygen purity obtained is $95.99 \%$. The SCOC-CC needs more water for cooling than the $\mathrm{CC}$ due to the dehumidifier, $\mathrm{CO}_{2}$, and $\mathrm{O}_{2}$ compressors intercooler stages. Despite the efficiency loss and higher water consumption, the SCOC-CC is more environmentally friendly since it can capture all or almost all $\mathrm{CO}_{2}$ produced in the combustion.

Future investigations will highlight the importance of feasibility analysis of the semi-closed oxy-fuel combustion combined cycle presented in this work. It is also essential to investigate the potential usage or storage methods of the captured $\mathrm{CO}_{2}$.

\section{Nomenclature}

\section{Variables}

$\mathrm{C}$ : number of carbon atoms in the fuel

$\mathrm{c}_{1}$ : learning parameter

$\mathrm{c}_{2}$ : learning parameter

Em $\mathrm{CO}_{2}$ : specific $\mathrm{CO}_{2}$ produced in the combustion process $(\mathrm{kg} / \mathrm{kWh})$

$\mathrm{e}_{\mathrm{ASU}}$ : ASU specific energy consumption $(\mathrm{kJ} / \mathrm{kg})$

$\mathrm{Em}_{\mathrm{CO} 2}$ : specific $\mathrm{CO}_{2}$ production $(\mathrm{g} / \mathrm{kWh})$

ex: exergy $(\mathrm{kJ} / \mathrm{kg})$

ex: specific exergy $(\mathrm{kJ} / \mathrm{kg})$

ex $\mathrm{ch}_{\mathrm{ch}, 0}$ : standard chemical exergy $(\mathrm{kJ} / \mathrm{kg})$

ex ${ }_{\mathrm{ch}}$ : chemical exergy $(\mathrm{kJ} / \mathrm{kg})$

exf: physical exergy $(\mathrm{kJ} / \mathrm{kg})$

$\mathrm{G}_{\text {best }}$ : best position found by the swarm

$\mathrm{H}$ : number of hydrogen atoms in the fuel

$\mathrm{h}$ : specific enthalpy $(\mathrm{kJ} / \mathrm{kg})$

$h_{0}$ : enthalpy in reference condition $(\mathrm{kJ} / \mathrm{kg})$

$\mathrm{i}$ : state point or index $\mathrm{i}$

I: irreversibility $(\mathrm{kW})$

$\mathrm{I}_{\text {tot }}$ : total plant irreversibility $(\mathrm{kW})$

LHV: lower heating value of fuel $(\mathrm{kJ} / \mathrm{kg})$

$\dot{\mathrm{m}}$ : mass flow rate $(\mathrm{kg} / \mathrm{s})$

$\mathrm{m}_{\mathrm{CO} 2 \text {,tot: }}$ total $\mathrm{CO}_{2}$ produced $(\mathrm{g} / \mathrm{h})$

$\mathrm{m}_{\text {fuel: }}$ fuel mass flow $(\mathrm{kg} / \mathrm{s})$;

P: pressure (bar)

$\mathrm{P}_{\text {best-i }}$ : best position found by the particle $\mathrm{i}$

pr: pressure ratio

Q: thermal energy rate $(\mathrm{kW})$

$\mathrm{R}$ : gas constant $(\mathrm{kJ} / \mathrm{kg}-\mathrm{K})$;

$\mathrm{r}_{1}$ : random independent variables between 0 and 1

$\mathrm{r}_{2}$ : random independent variables between 0 and 1

$\mathrm{s}$ : entropy $(\mathrm{kJ} / \mathrm{kg}-\mathrm{K})$

$s_{0}$ : entropy in reference condition $(\mathrm{kJ} / \mathrm{kg}-\mathrm{K})$

$\mathrm{T}$ : temperature $(\mathrm{K})$ $t_{\text {max }}$ : maximum number of iterations,

w: weight of inertia

$\dot{\mathrm{W}}$ : power $(\mathrm{kW})$

$\mathrm{W}_{\mathrm{GT}, \text { net }}$ : net power of gas turbine cycle $(\mathrm{kW})$

$\mathrm{W}_{\max }$ : maximum weight of inertia,

$\mathrm{W}_{\text {min }}$ : minimum weight of inertia.

$\mathrm{W}_{\mathrm{ST} \text {,net }}$ : net power of steam cycle $(\mathrm{kW})$

$\mathrm{x}$ : mass fraction

$\mathrm{y}$ : mass fraction

$\mathrm{y}_{\mathrm{O}_{2}}$ : oxygen purity (mol\%)

Greek letters

$\eta_{\mathrm{I}}$ : first law efficiency

$\eta_{\mathrm{II}}:$ second law efficiency

$\eta_{\text {isen }}$ : isentropic efficiency

$\eta_{\text {pol }}$ : the polytropic efficiency

$\beta$ : ratio of standard chemical exergy and lower heating

value of fuel

$\gamma$ : heat capacity ratio

Acronyms

ASU: air separation unit

CC: conventional combined cycle

CCS: carbon capture and storage

EES: Engineering Equation Solver

GT: gas turbine

HP ST: high-pressure steam turbine

HRSG: heat recovery steam generator

LHV: lower heating value

LP ST: low-pressure steam turbine

PSO: particle swarm optimization

SCOC-CC: semi-closed oxy-fuel combustion combined cycle

TIT: turbine inlet temperature

\section{References:}

[1] The United States Environmental Protection Agency (EPA), Overview of Greenhouse gases [Online]. Available:

https://www.epa.gov/ghgemissions/overviewgreenhouse-gases (accessed May 15, 2021).

[2] L. Zheng, Oxy-fuel combustion for power generation and carbon dioxide $\left(\mathrm{CO}_{2}\right)$ capture. Elsevier, 2011.

[3] B. Metz et al., Carbon dioxide and storage: special report of the intergovernmental panel on climate change. Cambridge University Press, 2005.

[4] M. Wilkinson et al., "Oxyfuel conversion of heater and boilers for CO2 capture" in $2^{\text {nd }}$ Annual Conference on Carbon Sequestration, Virginia (USA), 2003.

[5] National Energy Technology Laboratory, Commercial technologies for oxygen production. Available: https://www.netl.doe.gov/research/Coal/energysystems/gasification/gasifipedia/commercial-oxygen (accessed May 15, 2021).

[6] M. Maroto-Valer, Developments and innovation in carbon dioxide $\left(\mathrm{CO}_{2}\right)$ capture and storage technology: carbon dioxide $\left(\mathrm{CO}_{2}\right)$ capture, transport and industrial applications. Elsevier, 2010.

[7] S. G. Sundkvist et al., "Concept for a combustion system in oxyfuel gas turbine combined cycles," Journal of 
engineering for gas turbines and power, v. 136,n.10, 2014.

[8] J. Szargut, D. R. Morris, F.R Steward, Exergy analysis of thermal, chemical, and metallurgical processes. New York: Hemisphere, 1988.

[9] Y. Hu, H. Li, J. Yan, "Integration of evaporative gas turbine with oxy-fuel combustion for carbon dioxide capture," International Journal of Green Energy, 7(6), 615-631, 2010

[10] A. Ebrahimi et al., "Energetic, exergetic and economic assessment of oxygen production from two columns cryogenic air separation unit." Energy 90, 1298-1316, 2015 .

[11] H. M. Kvamsdal, K. Jordal, O. Bolland. "A quantitative comparison of gas turbine cycles with $\mathrm{CO} 2$ capture." Energy 32.1, 10-24, 2007.

[12] A. M. Y, Razak. Industrial gas turbines: performance and operability. Elsevier, 2007.

[13] A. L. Sheldrake, Handbook of electrical engineering for practitioners in the oil, gas and petrochemical industry, John Wiley \& Sons Ltd, Southern Gate, Chichester, 2003.

[14] O. Bolland, Thermal Power Generation, Department of Energy and Process Engineering - NTNU, 2010.

[15] R. Kehlhofer et al., Combined-cycle gas \& steam turbine power plants. PennWell Books, LLC, 2009.

[16] A. N. Dahlqvist (2016). Conceptual Thermodynamic Cycle and Aerodynamic Gas Turbine Design-on an Oxyfuel Combined Cycle (Doctoral dissertation), Lund University, Sweden.

[17] S. S. Maher, H.A Abid-Al-Rahman, Design of Dual Pressure Heat Recovery Steam Generator for Combined Power Plants [Online]. Available: http://confscoop.org/IEPEM-2013/11 Maher_IEPEM.pdf (accessed April 15, 2021).
[18] L. Bojici, C. Neaga. "Technical optimization of a twopressure level heat recovery steam generator." UPB Sci. Bull. Series D 74.2, 209-216, 2012.

[19] S. C. Gülen, Gas turbines for electric power generation, Cambridge University Press, 2019.

[20] GTW, Gas Turbine World: 2018 GTW Handbook (Vol. 33), Pequot Publishing.

[21] R. C. Eberhart, J. Kennedy, "Particle swarm optimization.", Proceedings of the IEEE international conference on neural networks, Vol. 4, Citeseer, 1995.

[22] A. F. Silva, A. C. Lemonge, Beatriz S. Lima "Algoritmo de Otimização com Enxame de Partículas auxiliado por Metamodelos.",XI Simpósio de Mecânica Computacional, II Encontro Mineiro de Modelagem SIMMEC/EMMCOMP, 2014.

Computacional

[23] Y. Shi, R. C. Eberhart, "Empirical study of particle swarm optimization.", Proceedings of the 1999 congress on evolutionary computation-CEC99 (Cat. No. 99TH8406). Vol. 3. IEEE, 1999.

[24] I. C. Trelea, "The particle swarm optimization algorithm: convergence analysis and parameter selection.", Information processing letters 85.6 (2003): 317-325.

[25] M. Juneja, S. K. Nagar. "Particle swarm optimization algorithm and its parameters: A review.",2016 International Conference on Control, Computing, Communication and Materials (ICCCCM). IEEE, 2016.

[26] N. Ferrari et al., "IEA GHG R\&D programme report: Oxy-turbine power plants”, 2015. 